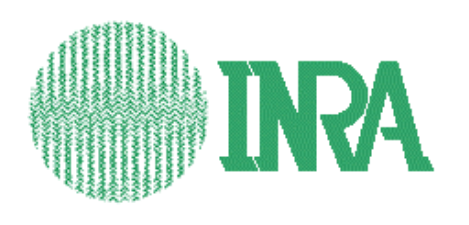

Institut National de la recherche Agronomique

Unité d'Economie et Sociologie Rurales

4 Allée Adolphe Bobierre, CS 61103

F 35011 Rennes Cedex

Tél. (33) 02234853 82/53 88 - Fax (33) 0223485380

http://www.rennes.inra.fr/economie/index.htm

Technical and scale efficiency of crop and livestock farms in Poland:

Does specialisation matter?

Laure LATRUFFE, Kelvin BALCOMBE, Sophia DAVIDOVA, and Katarzyna ZAWALINSKA

October 2002

Working Paper 02-06 


\title{
Technical and scale efficiency of crop and livestock farms in Poland:
}

\section{Does specialisation matter?}

\author{
Laure LATRUFFE \\ INRA - ESR Rennes and University of Paris 10 \\ Kelvin BALCOMBE \\ Imperial College at Wye \\ Sofia DAVIDOVA \\ Imperial College at Wye \\ Katarzyna ZAWALINSKA \\ ING Bank Slaski SA Scholar, University of Warsaw and CASE Foundation
}

\section{Acknowledgements}

The paper was written while Laure Latruffe was a visitor in Imperial College at Wye. The authors are very grateful to Lech Goraj from IERiGZ, Warsaw, for providing access to the data. They also thank Iain Fraser, Bernhard Brümmer and Alexander Gocht for their help, as well as Rob Fraser and Chantal Le Mouël for their comments.

\section{Corresponding address}

Laure LATRUFFE

INRA - Unité ESR

4 Allée Bobierre, CS 61103

35011 Rennes Cédex, France

Email: latruffe@roazhon.inra.fr 


\begin{abstract}
The paper analyses technical and scale efficiency of Polish farms using Data Envelopment Analysis. The focus is on efficiency differences according to farm specialisation, in crop or livestock, at two points in time during transition, 1996 and 2000. The statistical variability of efficiency estimates is investigated. The efficiency results are reviewed in the light of confidence intervals provided by bootstrapping and of a summary measure introduced in this study, 'the coefficient of separation'. The inference analysis suggests that farms might be less efficient than revealed by the point estimates alone, and that they might not be clearly different from each other.

On average, livestock farms are more technically and scale efficient than crop farms. Scale efficiency is high for both specialisations. Technical inefficiency appears mostly to be due to pure technical inefficiency rather than to scale inefficiency, thus to inefficient management practices. The low educational level of people engaged in agriculture is one important reason for these inefficient practices.

In 2000, 64 per cent of livestock farms and 86 per cent of crop farms were operating under increasing returns to scale. Improvements in the land lease legislation and changes to the policy support to farmers' pensions could stimulate the land market and remove the incentives to keep fragmented operational structure.
\end{abstract}

Keywords: Poland, farms, technical efficiency, specialisation, bootstrapping, discriminant anlaysis

JEL classification: D24, Q12

\title{
Résumé
}

L'efficacité technique et d'échelle des exploitations agricoles polonaises est estimée par la méthode Data Envelopment Analysis. L'étude porte sur les différences selon la spécialisation agricole, en élevage ou grandes cultures, à deux périodes pendant la transition, 1996 et 2000. Le papier examine de plus la variabilité statistique des estimations. Les résultats d'efficacité sont revus à la lumière des intervalles de confiance construits grâce au bootstrapping et d'une mesure introduite dans cette étude, 
le «coefficient de séparation ». Cette analyse d'inférence montre que les exploitations pourraient être moins efficaces que ce que les estimations seules révèlent, et qu'elles ne sont pas nettement différentiables de l'une de l'autre.

En moyenne, les exploitations d'élevage ont une efficacité technique et d'échelle supérieure aux exploitations de grandes cultures. L'efficacité d'échelle est toutefois très élevée pour les deux spécialisations. L'inefficacité technique semble donc due principalement à une inefficacité technique pure, c'est-à-dire à une gestion inefficace. La faible éducation des agriculteurs en est une raison majeure.

En 2000, 64 pour cent des exploitations d'élevage et 86 pour cent des exploitations de grandes cultures présentaient des retours d'échelle croissants. Ce résultat suggère des recommandations politiques afin de supprimer les incitations à garder une structure opérationnelle fragmentée et de stimuler la marché de la terre. Il s'agit en particulier d'améliorer la législation concernant la location des terres, et de modifier le système de retraite agricole.

Mots clé: Pologne, exploitations agricoles, efficacité technique, spécialisation, bootstrapping, analyse discriminante

Classification JEL: D24, Q12 


\title{
Technical and scale efficiency of crop and livestock farms in Poland: Does specialisation matter?
}

\author{
Laure LATRUFFE, Kelvin BALCOMBE, Sophia DAVIDOVA, and Katarzyna \\ ZAWALINSKA
}

\section{Introduction}

Poland is a frontrunner for accession to the European Union (EU) and the largest amongst the ten Central and Eastern European countries (CEECs) that are candidates for EU membership. According to the area and population, it accounts for approximately 10 per cent of the current EU-15 member-states. Its vast agricultural sector is playing a crucial role in land use and the employment of the rural population. Of the total area of 31 million ha, utilised agricultural area (UAA) accounts for 18.2 million ha, or 58.3 per cent (European Commission, 2002).

At the outset of the reform process, the initial conditions in Polish agriculture differed substantially from those in the other CEECs. Polish agriculture had never been fully collectivised and small-scale private farming prevailed during the whole period of central planning. When transition started, there was a strong belief that agriculture was the best prepared sector for the market economy due to its atomistic structure and longstanding freedom to decide on inputs and outputs without state intervention. However, it appears that the sector has been resistant to changes mainly due to the prevailing peasant-type farming (Mech, 1999). As structural change has been slow, agriculture's share of rural employment remains high and agricultural employment has not fallen by as much as was expected (OECD, 1995). According to the labour force survey, accounting for active persons only, there was a decline in the share of employment in agriculture and forestry from 22.1 per cent in 1996 to 18.8 per cent in 2000 (European Commission, 2002). However, the share of employment is still the second highest amongst the EU applicant countries after Romania, and it is much higher compared with the 4.3 per cent average in the EU-15. Agricultural labour productivity is low and, according to some estimates, in 1998 it was only 8.4 per cent of the average EU level 
(Pouliquen, 2001). In addition, according to this indicator, Poland is lagging behind most of the other CEECs. This suggests overmanning and disguised agricultural unemployment. At the same time, Polish farms seem to be much more capitalised than farms in the Czech Republic or Hungary (Davidova et al., 2002). All these facts raise a question about the efficiency of factor use in Polish farms.

The objective of this paper is to contribute to the empirical evidence on farm efficiency in transitional economies by studying the efficiency of farms in Poland. The paper investigates the technical and scale efficiency of Polish farms by applying Data Envelopment Analysis (DEA). What is asserted here is that ignoring the differences in output-mix impedes the proper identification of the problems of factor use. For this reason, the main focus of the study is on efficiency variations, according to farm specialisation in crop and livestock, and the main sources of difference between the two types of farms. The paper also investigates whether there are changes in these variations between two points in time during transition, namely 1996 and 2000.

The analysis accounts for the sampling noise in the efficiency estimates ignored in previous studies about farm efficiency in CEECs, with the exception of Brümmer (2001). It investigates the sampling variability of DEA point estimates by correcting for bias inherent in the DEA procedure and by providing confidence intervals. In the multioutput or multi-input cases, the bootstrap methodology is the only way to investigate the sampling variability of DEA point estimates (Simar and Wilson, 2000a). The bootstrapping procedure of Simar and Wilson (1998 and 2000b) is applied.

The paper is structured as follows. The next section provides a brief overview of previous studies of farm efficiency and productivity in Poland. The third section details the methodology, and the fourth section describes the data sets. Section five presents the results and section six discusses the policy implications.

\section{Previous studies of farm efficiency in Poland}

Studies about farm performance in the former communist countries focus mainly on the question of whether individual farms have an inherent efficiency superiority in comparison to corporate farms (Gorton and Davidova, 2002). However, the farming sector in Poland had never been extensively collectivised and, at the outset of the reform process, individual private farms accounted for 77 per cent of the Polish utilised agricultural area and employed 80 per cent of the total farm labour (OECD, 1995; 
European Commission, 1998). With the exception of a few studies that compared the private and socialised farming in the pre-reform Poland (Brada and King, 1993 and 1994), post-transitional research on Poland concentrated mainly on the relationship between efficiency (productivity) and size in individual private farms. Van Zyl et al. (1996) analysed the productivity and efficiency of farms in two regions, using data from 1993. The authors argued that there was a negative relationship between farm size and total factor productivity (TFP), as well as between size and technical efficiency estimated by DEA. They also reported that differences in scale efficiency between size groups were not statistically significant. This study, however, excluded farms smaller than 3 hectares. The exclusion of this size group provides an incomplete picture for Poland. According to the last agricultural census, in 200023.8 per cent of the farms were in the 1 to 2 ha size bracket, although they cultivated only 4.8 per cent of the UAA (GUS, 2001a). Munroe (2001), using stochastic frontier analysis on 1996 data, confirmed van Zyl et al.'s conclusions about the negative size-efficiency relationship. Mech (1999), employing data for the whole country for 7 years (1988-1994) and using TFP indices, found the opposite result, with farms larger than 15 ha being more productive. The latest studies, Davidova et al. (2002) and Lerman (2002), employing different methodologies, drew conclusions in line with Mech (1999). Davidova et al. (2002) analysed TFP of Polish farms in 1999 and reported that the differences in size between the groups of farms with TFP higher and lower than unity are significant, and that the productive farms are the larger ones. All mentioned studies, except Lerman (2002), used the panel data collected by the Polish Institute of Agricultural and Food Economics (IERiGZ), whilst Lerman used data for 2000 from a rural household survey. The results from his application of DEA were that the technical efficiency scores increased for larger farms. However, he argued that there was a quadratic pattern of variation of efficiency with farm size and the highest scores were achieved by the smallest farms, up to 2 ha, and the largest ones, over 30 ha. Obviously, even narrowing the discussion to the size-efficiency (productivity) relationship, the results are not consistent, and in addition, with the exception of Davidova et al. (2002) and Lerman (2002), they were based on data from the early stages of transition process.

This paper attempts to build on the existing studies by developing the investigation in two directions. First, by providing estimates of technical and scale efficiency on the latest available farm panel data for 2000 accounting for noise in the point estimates. Second, by investigating separately the efficiency of crop and livestock farms. 
Davidova et al. (2002) argue that the more productive farms in Poland tend to be more specialised in crop production. However, there is no detailed study analysing the efficiency variations in Polish farming according to specialisation.

\section{Methodology}

Farm efficiency was estimated by employing DEA. This method constructs a nonparametric frontier over data points, so that the observations lie on or below the frontier (for more details see Charnes et al., 1978; Färe et al.,1994; Thiele and Brodersen, 1999). The input-oriented model determines the minimal input efficiency measure. In addition to a proportional decrease in inputs in order for a farm to be efficient, there might be slacks that allow for further unproportional reduction of some inputs (Coelli et al., 1998). The output-oriented model measures the proportional increase in output that can be attained with constant input (Thiele and Brodersen, 1999). Slacks in this type of model give information about the possibility of an unproportional increase in some outputs.

DEA requires detailed data about inputs and outputs, and data sets containing micro accountancy data similar to Farm Accountancy Data Network (FADN) are usually used. The analysis could be performed at activity or farm level. Activity analysis, however, necessitates separability of inputs by activity.

As a deterministic method, DEA does not model explicitly a random error term and the overall deviation from the frontier is interpreted only as inefficiency. However, the accuracy of DEA results may be affected by sampling variation. In the input-oriented model, efficiency estimates might be biased towards higher scores (i.e. towards 1) whilst in the output model, efficiency estimates might be biased downwards if the farms that determine the frontier are not contained in the sample. Attention to the sampling noise in the efficiency estimates is growing in the literature, but previous studies about farm efficiency in CEECs generally ignore this problem. Only Brümmer (2001) considered it in a study about Slovenian farms. In the multi-output or multi-input cases, the bootstrap methodology is the only way to investigate the sampling variability of DEA point estimates, by correcting for bias inherent in the DEA procedure and by providing confidence intervals (Simar and Wilson, 2000a). The bootstrapping procedure relies on repeating the parameter estimation with data resampled by mimicking the data generating process, which in this case is the process generating the efficiency scores. 
The observed parameter distribution is taken to be an estimate of the true distribution (Brümmer, 2001).

DEA has been preferred in this study of Polish farms for several reasons. First, it allows estimating total technical efficiency and breaking it down to pure technical efficiency and scale efficiency, as well as identifying farms that are operating under decreasing or increasing returns to scale. Second, DEA does not require specification of a functional form for the frontier as it uses linear programming to construct a piece-wise frontier that envelops the observations of all farms. Third, conditional on data availability, DEA allows farms to be classified according to several criteria that are of interest in this study, e.g. size, specialisation, resource endowment (Jonasson and Apland, 1997). Fourth, multiple inputs and outputs can be considered simultaneously, and inputs and outputs can be quantified using different units of measurement.

This study employed an input-oriented single-output multi-input model, which was applied at the farm level using accountancy data similar to FADN. Total output in value was used as a single output variable. Four inputs were included: utilised agricultural area (UAA) in hectares as a land factor, annual work units (AWU) as a labour factor, depreciation plus interest as a capital factor, and intermediate consumption as a variable input factor. For 2000, all nominal values were deflated to adjust for the substantial inflation which persisted during the analysed period. Output was deflated by the index of agricultural output prices, depreciation and intermediate consumption by the index of agricultural input prices, and interest by the consumer price index. ${ }^{1}$ Ninety-five per cent confidence intervals were constructed using bootstrapping. The smoothed homogenous bootstrap and the procedure proposed by Simar and Wilson (1998 and 2000b) were applied. The procedure used is presented in appendix. The bandwidth parameters were chosen according to the normal reference rule (Simar and Wilson 2000b) and 2000 bootstrapping iterations were performed.

For both periods 1996 and 2000 crop and livestock farms were separated into two subsamples and a frontier was estimated for each specialisation. Farm specialisation was determined as a prevailing share of crop or livestock in the total farm output. This avoided the separation of crop and livestock enterprises and the allocation of enterprise

\footnotetext{
${ }^{1}$ Indices published by the Central Statistical Office (GUS) were used (GUS, 2001a).
} 
specific inputs that would have involved strong assumptions about factor allocation. Such an approach is common in farm efficiency studies where 'specialised' farms are defined according to the prevailing activities in their output mix. The threshold used in the efficiency studies that distinguishes between specialisations is rarely cited or justified. It is usually an arbitrary choice. Most of the farm efficiency studies for transitional economies use a low threshold, 50 per cent (Mathijs and Vranken, 2000; Kopeva and Noev, 2002). Only Mathijs et al. (1999) applied a 75 per cent threshold in a study of Czech farms. The specialisation criterion employed in this study was a share of minimum 65 per cent of the value of crop or livestock production in the total output. Although 65 per cent can appear low, this threshold is meaningful for a study on Poland where farms tend to be small and try to diversify their agricultural activities in order to decrease the risk inherent to farming.

The variables that can explain the differences between crop and livestock farms were studied by a discriminant analysis. The stepwise method was followed. The models were evaluated in terms of their ability to predict to which group the farms belong and the share of the variance they explain. As a variable representing the economic size of the farm, the value of total output was used. Two measures of intensification were employed. The first was the quantity of depreciation and interest per annual work unit, in which case higher values were used as proxies showing that there was more capital per worker employed, thus more capital-intensive technology. The second was the amount of land per annual work unit with larger scores indicating more extensive type of technology. Two variables accounting for the use of factor markets, the percentage of rented land and the percentage of paid labour, were included. Leverage, which shows the ratio of total liabilities to the net worth of the farm, indicated the use of the credit market and other external creditors. Environment characteristics were proxied by an index of land quality, and farmers' characteristics by farmers' age.

\section{Data used}

The study employed data from the annual survey of a sample of bookkeeping individual farms carried out by the Polish Institute of Agricultural and Food Economics (IERiGZ). The survey covered a large range of resource, output, management, and social variables on about 1,200-1,300 farms. This is panel data and only small changes brought about by the disappearance of some farms, mergers, or farmers refusing to continue their 
participation in the survey, are introduced from year to year. The farms are drawn from all 16 administrative regions in Poland.

For the present study, those farms which participated in both 1996 and 2000 surveys were selected, resulting in a sample size of 914 farms for each year. From these 914 farms, two sub-samples were constructed according to farm specialisation in crop and livestock. In 1996, there were 216 crop and 107 livestock farms and in 2000, 222 and 250 respectively. Only 78 of the livestock farms and 164 of the crop farms kept their specialisation and they were included in both 1996 and 2000 sub-samples. The remaining farms decreased their level of specialisation whilst other farms became more specialised and were included for analysis in 2000. Overall, between 1996 and 2000 more farms became specialised, particularly in livestock production.

As in the overall IERiGZ sample, all four sub-samples were not representative for the Polish farm population since they were biased towards larger farms. As mentioned, the 2000 agricultural census indicated that 23.8 per cent of the Polish farms had an average land area between 1-2 ha and only 9.9 per cent had more than 15 ha (GUS, 2001a). In the overall IERiGZ sample, these shares were 1.3 and 48 per cent respectively. This bias was due mainly to the fact that only farms keeping accountancy books were surveyed. In the four sub-samples used in the analysis, although farms in the smallest bracket were included, the proportion of farms above 15 ha was even higher than in the overall IERiGZ sample (Table 1). Studying larger farms is adequate for the present research, as the interest is in farms that have commercial activities and will have to compete in the market of the enlarged Union. The smallest farms that do not keep accounting books are likely to continue to produce for self-consumption and are not expected to be market integrated even after the EU accession.

\section{(Table 1)}

Some basic characteristics of the sample farms used later in the analysis are presented in Table 2. Crop farms had a larger mean UAA which increased by 6 ha between 1996 and 2000. The mean size of the livestock farms, measured by the land area, also increased but by less than 2 ha. Crop farms were also larger when size was measured by total output. In addition, the gap in the mean value of output between the two specialisations increased substantially between 1996 and 2000. When comparing size according to labour input, the difference between crop and livestock disappeared due to the more labour intensive character of livestock production. The standard deviation shows that, 
according to the three size measures, livestock farms are more clustered around the mean than crop farms. Livestock farms had less capital and land per one full-time employed person, and used land rental market and hired labour to a lesser extent. Thus, they relied more on family resources than the crop farms. They used less debt in comparison to the net worth of the farm (leverage), but in both specialisations the role of debt in running the business increased slightly between 1996 and 2000. Not surprisingly, farms that operated on a higher quality land had specialised in arable crop production.

(Table 2)

Concerning farmers' characteristics, in 1996 livestock farmers were older on average than crop farmers, but this difference had disappeared by 2000. In 2000, the average age of farmers in the sub-samples was 45-46 years. This reflects well one of the known facts about the Polish farmers, their high age.

\section{Results}

\subsection{Total technical, pure technical and scale efficiency}

Estimates of total technical, pure technical and scale efficiency are presented in Table 3. For each of the three efficiencies, the maximum score found within the samples is unity, therefore only minimums are reported here. The percentage of efficient farms represents the share of farms with an efficiency score of unity.

Livestock farms were on average more technically efficient than crop ones and a higher share of livestock farms had a score of unity. In 2000 the livestock farms had on average a total technical efficiency of 0.71 , meaning that they could reduce their inputs by 29 per cent and still produce the same level of output. The crop farms could reduce their inputs even more, by 43 per cent. The mean efficiency scores for both specialisations were lower in 2000 than in 1996, with less farms being perfectly efficient. $^{2}$ Whilst in 1996 the share of farms with a pure technical efficiency score of unity in the livestock sample was twice the share in the crop sample, it appears that

\footnotetext{
${ }^{2}$ As suggested by one referee, the data from both years 1996 and 2000 were pooled together and a single frontier was estimated for each specialisation. Under the hypothesis of the same frontier over the two periods, this DEA analysis confirmed the main findings. The livestock farms were on average more efficient than the crop farms and the efficiency decreased for both specialisations between 1996 and 2000. Both specialisations were highly scale efficient.
} 
livestock farms lost this advantage and in 2000 both specialisations had 10 per cent perfectly efficient farms.

\section{(Table 3)}

One of the possible reasons for the decrease in the mean efficiency between 1996 and 2000, particularly for the crop farms, could have been the influence of weather conditions. Both studied years were not very favourable for agriculture but without exceptional crop damages. Since 1995 arable crop output in Poland has fluctuated in parallel with the fluctuations in yields at around 3 tonnes/ha (European Commission, 2002). According to GUS, yields in the two studied years were within the expected range, but slightly higher in 1996 than in 2000 (GUS, 2001a).

The scale efficiency is high for both specialisations and at both points in time, with higher scores being recorded by livestock farms (Table 3). In 2000, the gap between the two specialisations increased, as the mean scale efficiency of crop farms dropped, whilst for livestock farms it remained unchanged. Although both specialisations are clustered towards high efficiency, crop farms are spread over a wider range of efficiency intervals.

The low pure technical efficiency in comparison to scale efficiency suggests that inefficiencies are mostly due to inefficient management practices. The large decrease in the mean pure technical efficiency of livestock farms between 1996 and 2000 might have resulted from the lack of adaptation of their management practices to the market requirements. However, the increase in the standard deviation for pure technical efficiency in livestock farms between 1996 and 2000 suggests that with the development of transition process some managers started adapting better to the market pressures. In the crop farms' sample there were not substantial changes in the mean pure technical efficiency and in the standard deviation during this period.

The test for constant returns to scale (CRS), increasing returns to scale (IRS) and decreasing returns to scale (DRS) shows that there are more scale efficient farms in the livestock sample (Table 4). In both time periods, crop farms mostly operated under IRS, meaning that they were too small. Thus, one of the important conclusions of these results is that, taking 2000 as a reference point, the bulk of the studied farms could gain efficiency by increasing in size.

(Table 4) 
However, half of the livestock farms were operating under DRS in 1996. By 2000 this share had decreased, but was still more than a quarter. This means that livestock farms were too large. Slacks were investigated to determine which inputs could be decreased unproportionally. Table 5 presents the average slacks for each input for the total technical efficiency.

\section{(Table 5)}

On average, livestock farms had land, labour and capital slacks. For example, in 1996 the livestock farms could have decreased their utilised land by 1.5 ha on average, their labour input by $0.1 \mathrm{AWU}$, and their value of capital by 1,920 Polish zloty (PLZ) and still achieved the same output. Expressed as a percentage of the input level, in 1996 the capital slack was the largest (21.3 per cent), followed by labour (5.8 per cent). All slacks decreased between 1996 and 2000. Intermediate consumption was not on average used in excess by livestock farms. In 1996 not a single livestock farms had slacks for intermediate consumption. In 2000, there was some average slack for the sub-sample but this was influenced by a few farms with large slacks. For the crop farms, labour, land and capital slacks increased between 1996 and 2000 with the main problem emerging around capital, with a share of slack in 2000 of nearly 11 per cent. Thus, capital appears to be inefficiently used in both crop and livestock farms.

\subsection{Size-efficiency relationship}

As underlined in the overview of the previous research on Poland, most of the studies about the performance of Polish farms during transition focused on the size-efficiency (productivity) relationship and the reported results have not been consistent.

Graphs 1 and 2 depict the pure technical efficiency scores in 2000 with respect to 7 size intervals. For both samples the curve is U-shaped. The most efficient farms were the smallest and the largest. The curve of pure technical efficiency for crop farms is not as clearly shaped as that for livestock farms, but once the largest size group (over 50 ha) is broken down by size intervals, then the U-shaped curve is also obvious in the crop sector. These results are similar to Lerman's (2002) findings about the low efficiency of mid-sized farms.

(Graph 1)

(Graph 2) 
Turning to the scale efficiency, in 2000 the smallest farms (between 1-2 and 2-5 ha) were the least efficient for both crop and livestock (Graphs 3 and 4). The same conclusions apply to 1996.

(Graph 3)

(Graph 4)

The results about efficiency in respect of the smallest farm size should be considered with caution because, as stated, the samples used were biased towards large farms. Only one or two farms of the smallest size interval, 1-2 ha, were included in the samples. However, an ANOVA analysis for each size-efficiency result was conducted and showed that farm size had a statistically significant impact on efficiency at 1 per cent level, except for the total and pure technical efficiency of livestock farms in 1996 (Table 6). This result contradicts the conclusions by van Zyl et al. (1996) on data for the first years of transition, who argued that the differences in scale efficiency between size groups were not significant.

(Table 6)

\subsection{Statistical variability}

The point estimates' confidence intervals constructed using bootstrapping give additional insight into efficiency estimation (Simar and Wilson, 2000a). The intervals are generally wide. The samples' average width ranges from 0.07 to 0.19 . It suggests that the farms might be more inefficient than revealed by the point estimates alone. For example, the mean pure technical efficiency of the 2000 livestock sample showed that the farms could in average attain the same level of output by reducing their inputs by 26 per cent. However, the confidence intervals suggest that on average inputs could be reduced by between 28 and 41 per cent. Farms originally identified being on the frontier, may in fact lie well below it. For example in 2000 , livestock farms with a pure technical efficiency score of 1 have an average lower confidence bound of 0.55 . The ranking of farms might be also different than originally estimated, as shown in Table 7. Bootstrapping reveals that with an average lower bound of 0.25 , the smallest group (1-2 ha) might not be the most efficient, although these farms were originally estimated to be full efficient. Moreover, there might not be any difference in mean efficiency between the five middle groups (from 2-5 ha to $15-50$ ha), since the confidence intervals are fairly similar for these groups.

(Table 7) 
In order to provide a summary statistic of the degree of overlap between confidence intervals, a useful measure is introduced in this study, which we call 'the coefficient of separation'. This statistic is calculated by taking each farm in turn and then identifying the farms in the sample that are significantly more efficient than it, that is to say the farms with a lower bound strictly greater than the upper bound for the farm in question. More precisely, the number $\mathrm{N}_{1}$ of farms with lower bound strictly greater than the upper bound for the considered farm is counted. By repeating this process, it can be found that $M_{1}$ farms in the sample have $N_{1}$ farms significantly more efficient than them; $M_{2}$ farms have $\mathrm{N}_{2}$ farms significantly more efficient etc. Graph 5 shows the relationship between the numbers $\mathrm{N}_{1}, \mathrm{~N}_{2} \ldots \mathrm{N}_{\mathrm{n}}$ and the numbers $\mathrm{M}_{1}, \mathrm{M}_{2} \ldots \mathrm{M}_{\mathrm{n}}$, expressed as percentages of the sample for total technical efficiency of livestock farms in 2000. The coefficient of separation for the estimated sample is given by the area under the curve in comparison with the area under the bold line that would have applied in the case of perfect separation. For example, here 5 per cent of the farms on $\mathrm{X}$-axis are significantly less efficient than 70 per cent of the farms on $\mathrm{Y}$-axis. If the farms were perfectly separated, the curve would be the bold straight line and 5 per cent of the farms would be significantly less efficient than 95 per cent of the farms.

\section{(Graph 5)}

In this example the coefficient of separation is 61 per cent. The coefficients for all other efficiency estimates were also low, between 41 per cent and 61 per cent, which is not a surprising result as wide intervals imply low separation. These measures show that it is difficult to identify farms that are significantly less or more efficient than the average.

Despite the weakness of the findings about farm ranking, confidence intervals supported the results about the efficiency variation between specialisations. Except for pure technical efficiency in 2000, the livestock and crop farms' average confidence intervals never overlapped, with livestock farms being more efficient than crop farms. The intervals also confirmed that between 1996 and 2000 the efficiency of livestock farms had decreased, but this finding could not be asserted with certainty for the crop farms.

\subsection{Determinants explaining the variations between crop and livestock farms}

As discussed above, livestock farms recorded higher efficiency scores for both analysed points in time and the interesting question is what are the variables that distinguish these 
farms from the crop ones. In order to investigate these variables, a discriminant analysis was run. The variables used are listed in Table 8 with F-statistics indicating whether their means are significantly different between crop and livestock farms. In 1996 and 2000 almost all variables were significantly different, except for the total output in 1996 and for the farmers' age in 2000. Therefore, it can be expected that the variables discriminate between the two specialisations.

(Table 8)

The results are presented in Table 9. In 1996, the total output, the land area per unit of labour, the share of hired labour and the soil quality index had the power to discriminate between crop and livestock farms. The same variables are included in the discriminant function of the year 2000, alongside the capital intensity. The discriminant functions are highly significant in both years. The hit ratio gives the percentage of farms that can be correctly classified with the discriminant function. It is high and greater than the percentages of random classification. These are represented by the prior probabilities (calculated with the size samples), namely 0.33 for the livestock sample and 0.67 for the crop sample in 1996, and 0.53 and 0.47 in 2000 respectively.

Both models correctly predict the farms' classification and are highly significant, although they explain little of the variance in the specialisation variable.

(Table 9)

Comparing the sign of the discriminant function at one group's centroid ${ }^{3}$ with the sign of the variables' coefficient allows the identification of which variable is expected to be greater for the group considered. Size and degree of intensification discriminate highly between livestock and crop farms, with crop farms being more capital intensive (only in 2000) and having more land per unit of labour, and livestock farms being larger in terms of total output value. Also, the share of hired labour is an important discriminating variable with crop farms relying more on external labour. However, the soil quality has the greatest discriminating power with crop farms having a higher soil quality index.

Although in the crop sample the mean total output is greater than the livestock output, the discriminant analysis shows that a farm with large total output is more likely to be a livestock farm. This gives an additional insight into the farms' distribution in terms of size represented by the total output. Large crop farms are few, however their total

\footnotetext{
${ }^{3}$ The centroid is the mean value of the discriminant score for a group (Hair et al., 1987).
} 
output is large enough to give a high sample mean. The fact that fewer crop than livestock farms are large is confirmed by the greater total output standard deviation for the crop farms. This finding offers a potential explanation for the crop farms lower scale efficiency mean and the greater share of crop farms operating under IRS.

\section{Discussion and conclusions}

The results of the analysis of technical and scale efficiency show that on average livestock farms were more technically and scale efficient than crop farms. Scale efficiency was high for both specialisations and in both time points, thus technical inefficiency appears to be mostly due to pure technical inefficiency. The test for CRS, IRS and DRS shows that in both time periods crop farms mostly operated under IRS, meaning that they were too small. Half of the livestock farms were operating under DRS in 1996 but by 2000 this share had decreased.

From the methodological point of view this paper employed bootstrapping to determine the variability of DEA efficiency estimates and to produce estimates that were bias corrected. The usefulness of providing efficiency estimates that contain less bias is selfevident. However, knowing the variability of efficiency estimates is enormously helpful when conducting and evaluating subsequent analyses. In the present study the variability of the estimates was found to be quite large, with confidence intervals sometimes in excess of 0.1 on average. The paper introduced a measure called 'the coefficient of separation'. This used bootstrapped efficiency variability estimates in order to give a summary of the degree with which efficiency estimates could be said to distinguish between different farms in a statistically significant sense. It indicated that many farms could not be considered statistically significantly different from many others, even when the point estimates of their efficiencies indicated otherwise. The methodological implications are that any subsequent analysis using DEA scores may contain significant biases since the use of noisy DEA scores may induce 'errors in variables bias' should they be used as explanatory variables. It may also explain the difficulty in assessing the importance of potential explanatory factors for efficiency. For example, knowing the variability of the DEA estimates produced in other studies, such as van Zyl et al. (1996), might help explaining the failure to detect any impact of size on efficiency. Therefore, it suggests that any DEA study should employ bootstrapping as standard practice providing the sample sizes are not so large as to make it impractical. 
From the policy point of view several of the findings need more extensive discussion because of their longer-term implications. The first is that farms with prevailing livestock production in their output-mix were more efficient than farms with prevailing specialisation in arable farming. The discriminant analysis shows that livestock farms relied mostly on family labour while crop farms had a higher share of hired labour in their labour input, they were more capital intensive and had more land per unit of labour. The fact that livestock farms relied mainly on family labour might help explaining why they were found to be on average more technically efficient. The family labour is in full control of the resources and technology and, as the only residual claimant, has incentives for the most efficient resource use. Moving to hired labour involves gains from task specialisation, but may also result in shirking that can bring about a wasteful resource use. However, the simple family farms face high capital costs and, therefore, use little capital (Allen and Lueck, 1998). Data in Tables 2 and 8 support these arguments, as livestock farms used much less capital and land per unit of labour.

However, Allen and Lueck's model predicts that family labour and family controlled production narrow to stages strongly influenced by the biological processes, thus, they are more suitable to crops and particularly to highly seasonal crops. The modern, more intensive, livestock technologies largely eliminate the influence of nature, and therefore farm organisations based on hired labour and benefiting from task specialisation are more often found in livestock. Despite this, empirical research on productivity and efficiency in economies in transition has often found that individual private farms in livestock production are more efficient (productive) in comparison to their larger counterparts in crop production, which are often corporate farms. This might be due to the less intensive livestock technologies applied in these countries during transition. Hughes (2000) shows that individual private farms in the Czech Republic have the highest average TFP score in livestock production, whilst they record the lowest productivity in crop production in comparison with various types of corporate farms that rely largely on hired labour. He asserts that the need for close personal attention in livestock farming implies that individual farming is most productive in livestock. Mathijs and Swinnen (2001) present evidence from East Germany in the first years after the reunification. They show slightly higher efficiency scores for total technical and scale efficiency for family farms in livestock as compared to crops. However, controversy still reigns and Mathijs et al. (1999) and Mathijs and Vranken (2000) argue that individual farms in the Czech Republic, Hungary and Slovakia are more efficient in 
crop production but not in dairy. Therefore, further research is necessary in order to confirm or reject the efficiency superiority of family type farming in livestock production during transition. What has been revealed in the current study might be a temporary situation. Once the transitional constraints, particularly those concerning the functioning of the land market, are removed crop farms would be able to increase to an efficient size and the efficiency relations between individual livestock and crop farms might change. Moving to a more intensive livestock technology might also undermine the positive effect of the reliance on family labour and might bring about a need for a higher task specialisation.

The second important result is that, in 2000,64 per cent of the livestock sample farms and 86 per cent of crop farms were operating under increasing returns to scale. Thus, substantial efficiency gains could be captured by increases in farm size. However, several impediments to farm consolidation exist in Poland, such as access to credit and imperfect land market. Land legislation is still not favourable to tenants and cannot stimulate the lease market (Pouliquen, 2001). During the transition, Poland also adopted a policy of high support to the farmers' pension scheme. In 1990, the Agricultural Social Security Fund (KRUS) was created with the provision that retirement pensions would be financed more than 90 per cent by the state (OECD, 1995). During the period 1998-2001, this support absorbed around 80 per cent of the agricultural budget (European Commission, 2002). Pensions play an important role for rural households and in 2000 the share of social security and other social benefits in the total household income was 22.8 per cent. However, in order to qualify as farmers and to be eligible for the subsidised pension, households need to keep at least one hectare of agricultural land. This is one of the main reasons why structural changes in Polish farming have been so slow and, instead of farm consolidation, the number of farms in the smallest bracket between 1 and 2 ha increased from 17.7 per cent in 1990 to 23.8 per cent in 2000 (GUS, 2001a). In order to remove the incentive to maintain this very fragmented operational structure, fundamental changes to support policies are required. In 2001, a new law was introduced but it incorporated incentives for farmers to give up farming only for early retirement. In addition, the provisions only applied to farmers who could transfer/sell at least 3 ha of land. Thus they did not target the farmers from the smallest farm size group which includes a huge number of farms with structural deficiencies. 
The 'overcapitalisation' of Polish farms is another issue revealed by the analysis. It seems counterintuitive. However, it should be remembered that capital was proxied by the amount of depreciation plus interest. To a great extent this finding suggests weaknesses in management decisions to purchase an extensive range of machinery and equipment irrespective of the farm size and the potential efficiency with which they could be used. Another contributing factor relates to government policies that have provided incentives to farm operators to make such decisions. The maintenance costs for the old and obsolete capital stock are high and they often require credit and involve interest payments. There is a plethora of reasons for this situation. During central planning, farmers wanted to be as independent from the state system as possible, thus they wanted to have their own machinery irrespective of farm size (IERiGZ, 2002). In this way, farms inherited old machinery and equipment that were still in use during the transition period. The post-transitional policy for subsidised credit for purchase of agricultural machinery might have encouraged inefficient investments. In addition, the larger farmers with a better financial capacity have invested in modern and more expensive equipment, whilst the bulk of the smaller farms invested in old second-hand machinery. The smallest farms allocate the highest percentage of depreciation in comparison to the original costs of capital (IERiGZ, 1998 and 2002). This might be explained by the old machinery they bought and the high replacement costs if farmers seek upgrading. Thus, Polish farms have slacks of obsolete capital that impede increases in efficiency.

Another important result is that the efficiency estimates showed that total technical inefficiency appears to be mostly due to pure technical inefficiency rather than to scale inefficiency; that is to say that inefficient management practices had a stronger influence than farm size. The fact that inefficiencies in Polish farming are mainly due to management practices is a substantive issue that may undermine the competitiveness of Polish farms post-accession. There are several reasons for this situation. First, as farming has traditionally been in private hands, the transitional reforms were not directly applied to this sector and agriculture became a buffer for many of the newly unemployed who did not have adequate training or experience in farming (Wilkin, 1999). Second, the low level of education of farmers might be a substantial constraint to increase in efficiency. The degree of utilisation of production factors increases with the increase in education. Several studies testing the effect of education on farm efficiency found a positive relationship (Wu, 1977; Stefanou and Saxena, 1988). In Poland, 43 per 
cent of people engaged in agriculture have only elementary education, compared to 13 per cent in industry and 8 per cent in services (European Commission, 2001). People in farming are 5 times less likely to have a university degree than people engaged in other sectors of the economy. In addition, part-time farming is wide-spread in Poland and dedication to farming might also have implications for efficiency. A study on Navarra, Spain, where farm structures are not very different from Poland with many small individual farms, reports that farms run by a part-time farmer are less productive in comparison with the full-time ones (Davidova et al., 2002). In Poland in 1996, only 11 per cent of the individual farm operators earned their income exclusively from agriculture and 30 per cent mainly from agriculture (European Commission, 2002). The remaining 60 per cent involved in agriculture were part-time and used farming as an additional source of income.

Improvement in human capital might be crucial for the future of Polish farming in the enlarged Union from two points of view. The first is to improve the technical efficiency of those who will stay in farming, and the second is to increase the opportunities for non-farm employment in order to allow farmers to exit from agriculture, thus decreasing the overmanning in the sector and facilitating farm consolidation. Improving human capital is a long-term task and involves various policy instruments from setting-up young farmers to focusing extension service advice on improved management practices and better factor use. It is a difficult challenge, but it is central to the future competitiveness of Polish agriculture. 


\section{References}

Allen, D. and Lueck, D. (1998). The nature of the farm. Journal of Law and Economics, XLI (October 1998): 343-386.

Brada, J. and King, A. (1993). Is private farming more efficient than socialized agriculture? Economica, 60: 41-56.

Brada, J. and King, A. (1994). Differences in the technical and allocative efficiency of private and socialized agricultural units in pre-transformation Poland. Economic Systems, 18(4): 363-376.

Brümmer, B. (2001). Estimating confidence intervals for technical efficiency: The case of private farms in Slovenia. European Review of Agricultural Economics, 28(3): 285-306.

Charnes, A., Cooper, W. and Rhodes, E. (1978). Measuring the efficiency of decision making units. European Journal of Operational Research, 2: 429-444.

Coelli, T., Rao, P. and Battese, G. (1998). An Introduction to Efficiency and Productivity Analysis. Kluwer Academic Publishers, Norwell, Massachusetts.

Davidova, S., Gorton, M., Ratinger, T., Zawalinska, K., Iraizoz, B., Kovacs, B. and Mizo, T. (2002). Poland. In: An Analysis of Competitiveness at the Farm Level in the CEECs. Joint Research Project IDARA, Working Paper 2/11, Chapter 6.3: 44-62.

European Commission (1998). Agricultural Situation and Prospects in the Central and Eastern Countries: Poland. Directorate General for Agriculture, Brussels.

European Commission (2001). The Economic Impact of Enlargement. Enlargement Papers, No 4 (June 2001). Directorate General for Economic and Financial Affairs, Brussels.

http://europa.eu.int/comm/economy_finance/publications/enlargement_papers.

European Commission (2002). Agricultural Situation in the Candidate Countries. Country Report on Poland. Directorate General for Agriculture, Brussels.

Färe, R., Grosskopf, S. and Lovell, C. (1994). Production Frontiers. Cambridge University Press, USA. 
Gorton, M. and Davidova, S. (2002). Farm productivity and efficiency in the CEE applicant countries: A synthesis of results. Agricultural Economics, forthcoming.

GUS (2001a). Yearbook 2000. Warsaw.

GUS (2001b). Charakterystyka Gospodarstw Rolnych w $2000 \mathrm{r}$. Warsaw.

Hair, J., Anderson, R., Tatham, R. (1987). Multivariate Data Analysis. Second Edition, Macmillan, USA.

Hughes, G. (2000). Agricultural Decollectivisation in Central Europe and the Productivity of Emergent Farm Structures. PhD Thesis, Wye College, University of London.

IERiGZ (1998). Produkcyjno-Ekonomiczna Sytuacja Gospodarstw Prowadzacych Rachunkowosc rolna $w$ latach 1994-1996. Instytut Ekonomiki Rolnictwa i Gospodarki Zywnosciowej, Warsaw.

IERiGZ (2002). Produkcyjno-Ekonomiczna Sytuacja Gospodarstw Prowadzacych Rachunkowosc rolna $w$ latach 1998-2000. Instytut Ekonomiki Rolnictwa i Gospodarki Zywnosciowej, Warsaw.

Jonasson, L. and Apland, J. (1997). Frontier technologies and inefficiencies in programming sector models: An application to Swedish agriculture. European Review of Agricultural Economics, 24: 109-131.

Kopeva, D. and Noev, N. (2002). Technical efficiency and competitiveness of farms in transition: Lessons from Bulgaria. IAMO Series Agriculture and Food Industry in Central and Eastern Europe, IAMO Halle/Salle, Germany, forthcoming.

Lerman, Z. (2002). Productivity and Efficiency of Individual Farms in Poland: A Case for Land Consolidation. Selected Paper, American Agricultural Economics Association Annual Meeting, July 28-31, 2002, Long Beach, California.

Mathijs, E., Dries, L., Doucha, T. and Swinnen, J. (1999). Production efficiency and organization of Czech agriculture. Bulgarian Journal of Agricutural Science, 5: 312324.

Mathijs, E. and Swinnen, J. (2001). Production organization and efficiency during transition: An empirical analysis of East German agriculture. The Review of Economics and Statistics, 83(1): 100-107. 
Mathijs, E. and Vranken, L. (2000). Farm Restructuring and Efficiency in Transition: Evidence from Bulgaria and Hungary. Selected Paper, American Agricultural Economics Association Annual Meeting, July 30 - August 2, 2000, Tampa, Florida,.

Mech, D.-M. (1999). The Survival of Peasant Agriculture in Poland. PhD Thesis, Wye College, University of London.

Munroe, D. (2001). Economic efficiency in Polish peasant farming: An international perspective. Regional Studies, 35(2): 461-471.

OECD (1995). Review of Agricultural Policies: Poland. Organisation for Economic CoOperation and Development, Paris.

Pouliquen, A. (2001). Compétitivités et Revenus agricoles dans les Secteurs agroalimentaires des PECO: Implications avant et après Adhésion pour les Marchés et les Politiques de l'UE. Octobre 2001.

http://europa.eu.int/comm/agriculture/publi/reports/ceeccomp/fullrep_fr.pdf

Simar, L. and Wilson, P. (1998). Sensitivity analysis of efficiency scores: How to bootstrap in nonparametric frontier models. Management Science, 44(1): 49-61.

Simar, L. and Wilson, P. (2000a). A general methodology for bootstrapping in nonparametric frontier models. Journal of Applied Statistics, 27(6): 779-802.

Simar, L. and Wilson, P. (2000b). Statistical inference in nonparametric frontier models: The state of the art. Journal of Productivity Analysis, 13(1): 49-78.

Stefanou, S. and Saxena, S. (1988). Education, experience and allocative efficiency: A dual approach. American Journal of Agricultural Economics, 2: 338-345.

Thiele, H. and Brodersen, C. (1999). Differences in farm efficiency in West and East Germany. European Review of Agricultural Economics, 26(3): 331-347.

van Zyl, J., Miller, W., and Parker, A. (1996). Agrarian Structure in Poland: The Myth of Large Farm Superiority. Policy Research Working Paper No 1596, The World Bank, Washington D.C.

Wilkin, J. (1999). The economics of agricultural and rural areas in Poland: Basic problems and directions for development. Eastern European Countryside 5, Torun.

Wu, C. (1977). Education in farm production: The case of Taiwan. American Journal of Agricultural Economics, 59: 699-709. 


\section{Appendix}

Bootstrapping procedure

(i) With the smoothed bootstrap, an estimate of the original DEA efficiency scores (denoted as $\hat{\theta}_{i}$ for the $\mathrm{i}$-th farm) for $\mathrm{i}=1, \ldots, \mathrm{N}$, is obtained, with $\mathrm{N}$ the number of farms in the sample. A random sample of the original size $(\mathrm{N})$ is drawn from this smooth estimate, and is denoted $\hat{\theta}_{\mathrm{i}, \mathrm{b}} *$ for $\mathrm{i}=1, \ldots, \mathrm{N}$.

(ii) For $\mathrm{i}=1, \ldots, \mathrm{N}$, a pseudo data set of $\left(\mathrm{x}_{\mathrm{i}, \mathrm{b}} * \mathrm{y}_{\mathrm{i}, \mathrm{b}} *\right)$ is constructed, where $\mathrm{y}_{\mathrm{i}} *$ is the original output level $\mathrm{y}_{\mathrm{i}, \mathrm{b}} *=\mathrm{y}_{\mathrm{i}}$, and $\mathrm{x}_{\mathrm{i}, \mathrm{b}} *$ is the constructed pseudo input level $\mathrm{x}_{\mathrm{i}, \mathrm{b}} *=\left(\hat{\theta}_{\mathrm{i}} / \theta_{\mathrm{i}, \mathrm{b}} *\right) \mathrm{x}_{\mathrm{i}}$, with $\mathrm{y}_{\mathrm{i}}$ and $\mathrm{x}_{\mathrm{i}}$ respectively the original output and input vectors of the i-th farm.

(iii) A new DEA efficiency score is calculated for each farm by taking the pseudo data as a reference, i.e. the following program is solved for $\mathrm{i}=1, \ldots, \mathrm{N}$ :

$$
\min _{\lambda, \hat{\theta}_{i, b} *} \hat{\theta}_{\mathrm{i}, \mathrm{b}} *
$$

$$
\begin{array}{ll}
\text { subject to } & -\mathrm{y}_{\mathrm{i}}+\mathrm{Y}_{\mathrm{b}} * \lambda \geq 0 \\
& \hat{\theta}_{\mathrm{i}, \mathrm{b}} * \mathrm{x}_{\mathrm{i}}-\mathrm{X}_{\mathrm{b}} * \lambda \geq 0 \\
& \lambda \geq 0
\end{array}
$$

where $\lambda$ is a Nx1 vector of constants.

(iv) Steps (i) to (iii) are repeated B times to yield a set of B new DEA efficiency scores $\hat{\theta}_{i, b} *$ for $b=1, \ldots, B$ and $i=1, \ldots, N$.

From this procedure the construction of confidence intervals can be based on bootstrap percentiles (Simar and Wilson, 1998). However, the DEA estimators need to be corrected for bias and this introduces additional noise (Simar and Wilson, 2000b). Simar and Wilson (2000b) propose a procedure that automatically corrects for bias. For a $(1-\alpha)$ per cent confidence interval, it starts from the following probability:

$$
\operatorname{Pr}\left(-\mathrm{a}_{\alpha} \leq \hat{\theta}_{\mathrm{i}}-\theta_{\mathrm{i}} \leq-\mathrm{b}_{\alpha}\right)=1-\alpha
$$

where $\theta_{\mathrm{i}}$ denotes the real efficiency score of the $\mathrm{i}$-th farm.

Since the distribution $\left(\hat{\theta}_{\mathrm{i}}-\theta_{\mathrm{i}}\right)$ can be approximated by the distribution $\left(\hat{\theta}_{\mathrm{i}} *-\hat{\theta}_{\mathrm{i}}\right), \mathrm{a}_{\alpha}$ and $b_{\alpha}$ can be estimated with the following probability: 


$$
\operatorname{Pr}\left(-\hat{\mathrm{a}}_{\alpha} \leq \hat{\theta}_{\mathrm{i}}^{*}-\hat{\theta}_{\mathrm{i}} \leq-\hat{\mathrm{b}}_{\alpha}\right)=1-\alpha
$$

Finding $\hat{a}_{\alpha}$ and $\hat{b}_{\alpha}$ involves sorting the values $\left(\hat{\theta}_{\mathrm{i}, \mathrm{b}} *-\hat{\theta}_{\mathrm{i}}\right)$ for $\mathrm{b}=1, \ldots, \mathrm{B}$ in increasing order and then deleting the $(\alpha / 2) \times 100$-per cent of the elements at either end of the sorted list. $-\hat{a}_{\alpha}$ and $-\hat{b}_{\alpha}$ are equal to the end points of the truncated array, with $\hat{a}_{\alpha} \leq \hat{b}_{\alpha}$. Thus, the estimated $(1-\alpha)$ per cent confidence interval for the efficiency $\theta_{\mathrm{i}}$ of the $\mathrm{i}$-th farm is:

$$
\hat{\theta}_{i}+\hat{a}_{\alpha} \leq \theta_{i} \leq \hat{\theta}_{i}+\hat{b}_{\alpha} .
$$


Table 1: Distribution of the sample farms according to area in hectares $(\%)^{1}$

\begin{tabular}{|c|c|c|c|c|c|c|c|}
\hline \multirow[t]{2}{*}{ Farm specialisation } & \multicolumn{3}{|c|}{ Small farms } & \multicolumn{2}{|c|}{ Medium farms } & \multicolumn{2}{|c|}{ Large farms } \\
\hline & $1-2$ & $2.01-5$ & $5.01-7$ & $7.01-10$ & $10.01-15$ & $15.01-50$ & $>50$ \\
\hline \multicolumn{8}{|l|}{1996} \\
\hline Livestock & 0.9 & 14.0 & 5.6 & 13.1 & 21.5 & 37.4 & 7.5 \\
\hline Crop & 0.0 & 5.6 & 9.3 & 13.9 & 11.6 & 35.2 & 24.5 \\
\hline \multicolumn{8}{|l|}{2000} \\
\hline Livestock & 0.4 & 9.2 & 9.2 & 8.8 & 19.2 & 44.4 & 8.8 \\
\hline Crop & 0.9 & 8.1 & 8.1 & 14.4 & 9.5 & 32.9 & 26.1 \\
\hline
\end{tabular}

${ }^{1}$ The classification into small, medium-sized and large reflects the farm distribution in Poland. If it is compared with other countries, most of the farms should be categorised as small. 
Table 2: Basic characteristics of the sample farms: Descriptive statistics

\begin{tabular}{|c|c|c|c|c|c|c|c|c|}
\hline \multirow[b]{2}{*}{ Variables } & \multicolumn{4}{|c|}{ Livestock farms } & \multicolumn{4}{|c|}{ Crop farms } \\
\hline & Mean & $\begin{array}{l}\text { Standard } \\
\text { deviation }\end{array}$ & Minimum & Maximum & Mean & $\begin{array}{l}\text { Standard } \\
\text { deviation }\end{array}$ & Minimum & Maximum \\
\hline & & & & 1996 & & & & \\
\hline Total output (000 PLZ) & 93.5 & 122.1 & 6.7 & 718.8 & 96.5 & 125.8 & 6.4 & $1,078.1$ \\
\hline Land (ha) & 19.8 & 20.5 & 1.3 & 126.6 & 42.3 & 75.6 & 2.3 & 754.5 \\
\hline Labour (AWU) & 2.16 & 1.11 & 0.40 & 6.64 & 2.29 & 2.17 & 0.17 & 23.35 \\
\hline Capital (000 PLZ) & 8.3 & 9.8 & 0.3 & 50.4 & 11.6 & 13.7 & 0.4 & 107.6 \\
\hline $\begin{array}{l}\text { Intermediate consumption } \\
\text { (000 PLZ) }\end{array}$ & 68.7 & 95.0 & 4.0 & 554.0 & 52.9 & 74.5 & 3.0 & 707.0 \\
\hline Capital / Labour (000 PLZ) & 3.4 & 2.5 & 0.4 & 13.2 & 5.2 & 6.5 & 0.7 & 84.3 \\
\hline Land / Labour (ha) & 8.6 & 6.4 & 1.5 & 41.6 & 16.9 & 19.8 & 1.5 & 203.3 \\
\hline Hired labour (\%) & 4.6 & 11.1 & 0 & 58.4 & 12.5 & 19.1 & 0 & 93.2 \\
\hline Rented land (\%) & 16.9 & 24.0 & 0 & 96.3 & 24.0 & 30.0 & 0 & 100 \\
\hline Leverage & 0.02 & 0.04 & 0 & 0.20 & 0.06 & 0.15 & 0 & 1.40 \\
\hline Soil quality index ${ }^{1}$ & 0.73 & 0.28 & 0.17 & 1.45 & 1.02 & 0.27 & 0.35 & 1.61 \\
\hline Age & 46.0 & 11.2 & 28.0 & 78.0 & 42.5 & 9.6 & 15.0 & 74.0 \\
\hline & & & & 2000 & & & & \\
\hline Total output (000 PLZ) & 96.1 & 114.2 & 6.8 & 732.3 & 124.5 & 213.0 & 2.1 & $1,949.8$ \\
\hline Land (ha) & 21.4 & 20.1 & 1.1 & 161.0 & 48.3 & 84.1 & 1.6 & 754.5 \\
\hline Labour (AWU) & 2.01 & 0.99 & 0.33 & 8.02 & 1.95 & 2.33 & 0.07 & 27.1 \\
\hline Capital (000 PLZ) & 10.4 & 11.4 & 0.4 & 92.1 & 18.0 & 26.6 & 0.6 & 266.3 \\
\hline $\begin{array}{l}\text { Intermediate consumption } \\
\text { (000 PLZ) }\end{array}$ & 75.5 & 99.7 & 5.1 & 689.2 & 86.1 & 143.6 & 4.0 & $1,478.5$ \\
\hline Capital / Labour (000 PLZ) & 4.8 & 3.8 & 0.4 & 26.0 & 9.6 & 7.7 & 1.2 & 54.8 \\
\hline Land / Labour (ha) & 10.2 & 6.9 & 1.8 & 48.4 & 23.2 & 21.9 & 1.6 & 117.3 \\
\hline Hired labour (\%) & 6.9 & 12.3 & 0 & 72.1 & 13.5 & 19.3 & 0 & 91.9 \\
\hline Rented land (\%) & 17.7 & 21.3 & 0 & 96.0 & 23.0 & 27.4 & 0 & 100 \\
\hline Leverage & 0.04 & 0.06 & 0 & 0.37 & 0.08 & 0.15 & 0 & 0.94 \\
\hline Soil quality index ${ }^{1}$ & 0.75 & 0.27 & 0.15 & 1.43 & 1.01 & 0.27 & 0.31 & 1.61 \\
\hline Age & 46.0 & 11.2 & 20.0 & 84.0 & 45.3 & 9.3 & 22.0 & 74.0 \\
\hline
\end{tabular}

${ }^{1}$ The soil quality index is based on a soil survey. Smaller values represent lower soil quality. The range in the sample was between 0.17 and 1.61 in 1996 and between 0.15 and 1.61 in 2000 . 
Table 3: Descriptive results of efficiency estimates

\begin{tabular}{|c|c|c|c|c|}
\hline $\begin{array}{c}\text { Farm } \\
\text { specialisation } \\
\text { (sample's size) }\end{array}$ & Mean & $\begin{array}{l}\text { Standard } \\
\text { deviation }\end{array}$ & Minimum & $\begin{array}{c}\text { Share of farms } \\
\text { fully efficient } \\
(\%)\end{array}$ \\
\hline \multicolumn{5}{|c|}{ Total technical efficiency } \\
\hline \multicolumn{5}{|l|}{1996} \\
\hline Livestock (107) & 0.85 & 0.11 & 0.57 & 10 \\
\hline Crop (216) & 0.66 & 0.18 & 0.21 & 6 \\
\hline \multicolumn{5}{|l|}{2000} \\
\hline Livestock (250) & 0.71 & 0.15 & 0.38 & 7 \\
\hline Crop (222) & 0.57 & 0.18 & 0.18 & 3 \\
\hline
\end{tabular}

Pure technical efficiency

\begin{tabular}{|c|c|c|c|c|}
\hline Livestock (107) & 0.88 & 0.10 & 0.58 & 20 \\
\hline Crop (216) & 0.70 & 0.17 & 0.28 & 10 \\
\hline \multicolumn{5}{|l|}{2000} \\
\hline Livestock (250) & 0.74 & 0.15 & 0.41 & 10 \\
\hline Crop (222) & 0.67 & 0.18 & 0.28 & 10 \\
\hline \multicolumn{5}{|c|}{ Scale efficiency } \\
\hline \multicolumn{5}{|l|}{1996} \\
\hline Livestock (107) & 0.97 & 0.05 & 0.68 & 13 \\
\hline Crop (216) & 0.93 & 0.10 & 0.36 & 6 \\
\hline \multicolumn{5}{|l|}{2000} \\
\hline Livestock (250) & 0.97 & 0.06 & 0.68 & 10 \\
\hline Crop (222) & 0.86 & 0.17 & 0.18 & 3 \\
\hline
\end{tabular}


Table 4: Shares of farms under CRS (scale efficient), IRS and DRS

\begin{tabular}{cccc}
\hline $\begin{array}{c}\text { Specialisation } \\
(\text { sample's size })\end{array}$ & $\begin{array}{c}\text { Scale efficient farms } \\
(\%)\end{array}$ & $\begin{array}{c}\text { Farms under DRS } \\
(\%)\end{array}$ & $\begin{array}{c}\text { Farms under IRS } \\
(\%)\end{array}$ \\
\hline 1996 & 13 & 50 & 37 \\
Livestock (107) & 6 & 16 & 78 \\
Crop (216) & 10 & & 64 \\
\hline Livestock (250) & 3 & 11 & 86 \\
Crop (22) & & 26 & \\
\hline
\end{tabular}


Table 5: Input slacks for the total technical efficiency

\begin{tabular}{|c|c|c|c|c|c|c|c|c|}
\hline \multirow{2}{*}{$\begin{array}{c}\text { Farm } \\
\text { specialisation }\end{array}$} & \multicolumn{4}{|c|}{ Input slacks (sample's mean) } & \multicolumn{4}{|c|}{ Slacks as percentage of input level (sample's mean) } \\
\hline & $\begin{array}{l}\text { Land } \\
\text { (ha) }\end{array}$ & $\begin{array}{l}\text { Labour } \\
\text { (AWU) }\end{array}$ & $\begin{array}{c}\text { Capital } \\
\text { (000 PLZ) }\end{array}$ & $\begin{array}{c}\text { Intermediate } \\
\text { consumption } \\
\text { (000 PLZ) }\end{array}$ & $\begin{array}{l}\text { Land } \\
(\%)\end{array}$ & $\begin{array}{c}\text { Labour } \\
(\%)\end{array}$ & $\begin{array}{c}\text { Capital } \\
(\%)\end{array}$ & $\begin{array}{c}\text { Intermediate } \\
\text { consumption } \\
(\%)\end{array}$ \\
\hline \multicolumn{9}{|l|}{1996} \\
\hline Livestock & 1.45 & 0.10 & 1.92 & 0.00 & 3.6 & 5.8 & 21.3 & 0.0 \\
\hline Crop & 3.47 & 0.04 & 1.97 & 1.76 & 3.5 & 2.2 & 9.4 & 1.0 \\
\hline \multicolumn{9}{|l|}{2000} \\
\hline Livestock & 1.16 & 0.25 & 0.69 & 0.41 & 2.5 & 1.3 & 3.9 & 0.1 \\
\hline Crop & 2.79 & 0.09 & 2.87 & 1.16 & 4.0 & 4.8 & 10.6 & 0.8 \\
\hline
\end{tabular}


Table 6: Impact of size on efficiency: ANOVA analysis, F-test statistics

\begin{tabular}{lccc}
\hline \multicolumn{1}{c}{$\begin{array}{c}\text { Farm } \\
\text { specialisation }\end{array}$} & $\begin{array}{c}\text { Total technical } \\
\text { efficiency }\end{array}$ & $\begin{array}{c}\text { Pure technical } \\
\text { efficiency }\end{array}$ & $\begin{array}{c}\text { Scale } \\
\text { efficiency }\end{array}$ \\
\hline 1996 & 0.46 & 1.15 & $6.87 * * *$ \\
Livestock & $7.33 * * *$ & $8.59 * * *$ & $36.5 * * *$ \\
Crop & & & $20.9 * * *$ \\
\hline 2000 & $2.39 * *$ & $6.25 * * *$ & $6.7 * *$ \\
Livestock & $4.52 * * *$ & & \\
Crop & & & \\
$*, * * *, * * *$ significance at $10 \%, 5 \%, 1 \%$ & &
\end{tabular}


Table 7: Pure technical efficiency estimates and confidence interval bounds of livestock farms according to size, 2000

\begin{tabular}{lccccccc} 
Size intervals (ha) & $1-2$ & $2-5$ & $5-7$ & $7-10$ & $10-15$ & $15-50$ & $>50$ \\
\hline Point estimate & 1.00 & 0.81 & 0.73 & 0.71 & 0.69 & 0.73 & 0.83 \\
\hline Lower bound & 0.25 & 0.54 & 0.58 & 0.60 & 0.60 & 0.61 & 0.51 \\
Upper bound & 0.98 & 0.79 & 0.71 & 0.70 & 0.67 & 0.71 & 0.81
\end{tabular}


Table 8: Variables included in the discriminant analysis; Significance of the difference between the crop and livestock samples' means (F-test)

\begin{tabular}{lcc}
\hline \multicolumn{1}{c}{ Variables } & \multicolumn{2}{c}{ F-test } \\
& 1996 & 2000 \\
\hline Total output (000 PZL) & 0.04 & $3.36 *$ \\
Capital / Labour (000 PZL) & $7.98 * * *$ & $77.87 * * *$ \\
Land / Labour (ha) & $17.69 * * *$ & $80.00 * * *$ \\
Share of hired labour (\%) & $15.89 * * *$ & $20.03 * * *$ \\
Share of rented land (\%) & $4.51 * *$ & $5.64 * *$ \\
Leverage & $8.09 * * *$ & $13.58 * * *$ \\
Soil quality index & $72.2 * * *$ & $111.2 * * *$ \\
Age & $8.43 * * *$ & 0.54 \\
\hline
\end{tabular}

$*, * * *, * * *$ : significance at $10 \%, 5 \%, 1 \%$ 
Table 9: Results of the discriminant analysis

\begin{tabular}{lcc}
\hline \multicolumn{1}{c}{ Function variables } & 1996 & \\
Total output & Function coefficients & Function significance \\
Land / Labour & -0.61 & $1 \%$ \\
Share of hired labour & 0.60 & $\%$ of the variance explained \\
Soil quality index & 0.62 & 33.1 \\
$\quad$ Function at group centroids & 0.87 & Hit ratio \\
Livestock & -1.00 & $80.8 \%$ \\
Crop & 0.49 & \\
\hline & 2000 & Function significance \\
$\quad$ Function variables & Function coefficients & \\
Total output & -0.48 & Hit ratio \\
Capital / Labour & 0.24 & $77.5 \%$ \\
Land / Labour & 0.64 & \\
Share of hired labour & 0.27 & \\
Soil quality index & 0.77 & \\
Function at group centroids & -0.73 & \\
Livestock & 0.82 & \\
Crop & & \\
\hline
\end{tabular}


Graph 1: Pure technical efficiency for livestock farms according to size (2000)

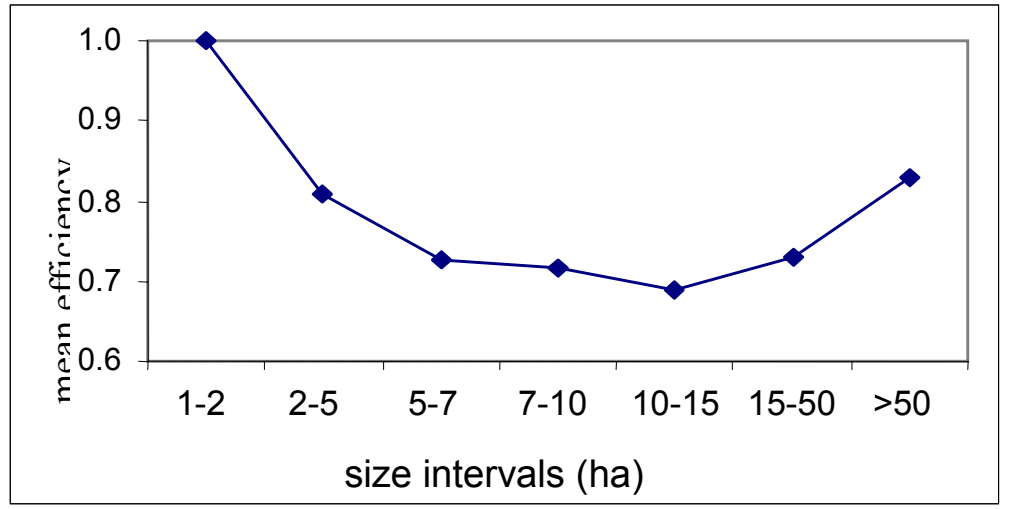


Graph 2: Pure technical efficiency for crop farms according to size (2000)

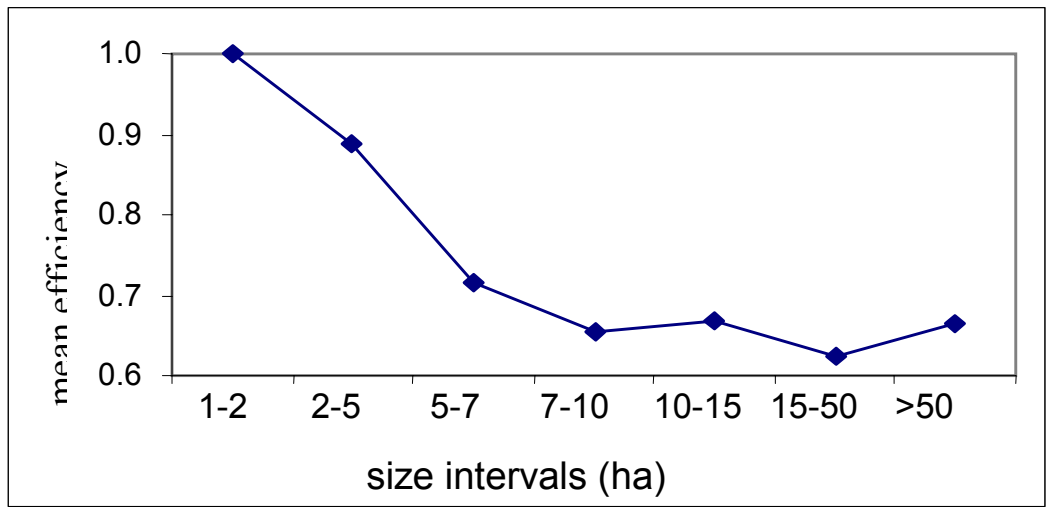


Graph 3: Scale efficiency for livestock farms according to size (2000)

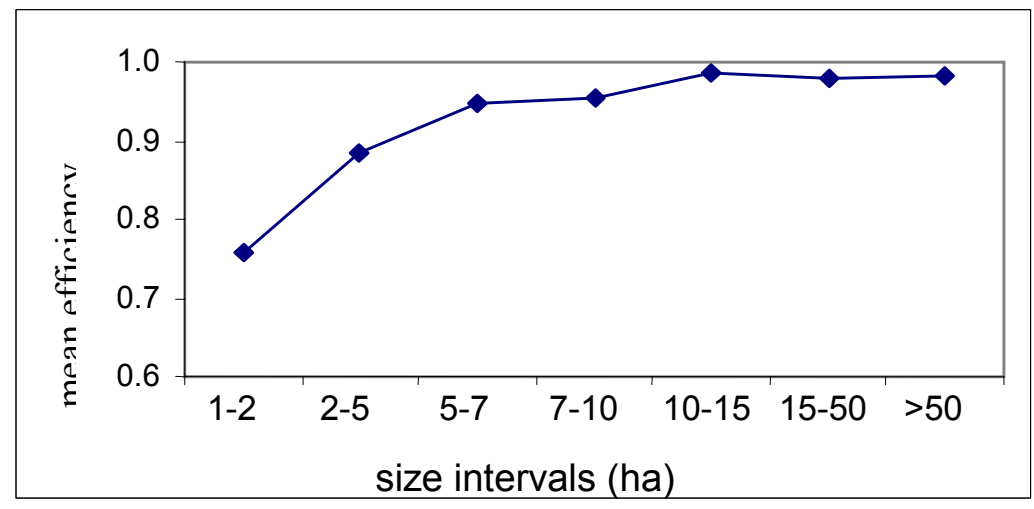


Graph 4: Scale efficiency for crop farms according to size (2000)

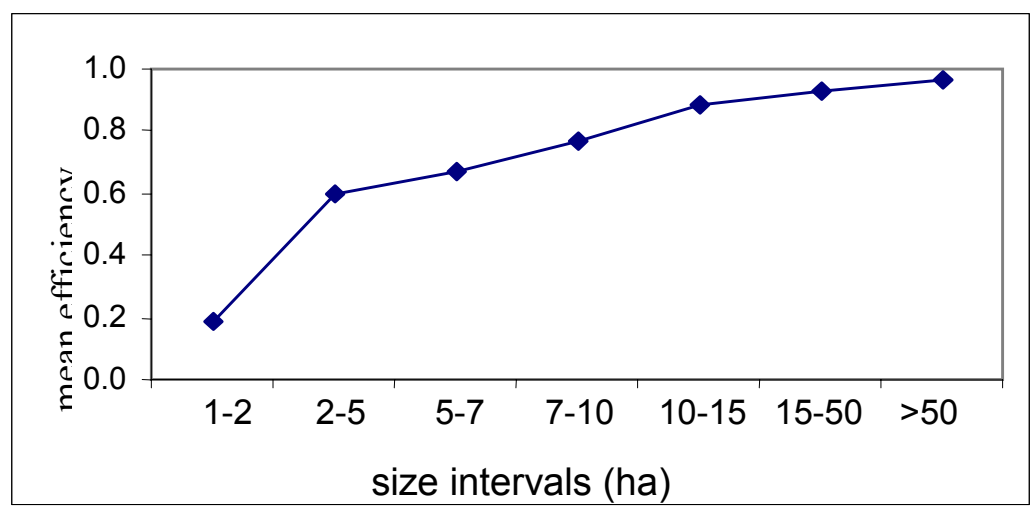


Graph 5: Separation of farms using confidence bounds: livestock farms, total technical efficiency, 2000 (\% of total sample)

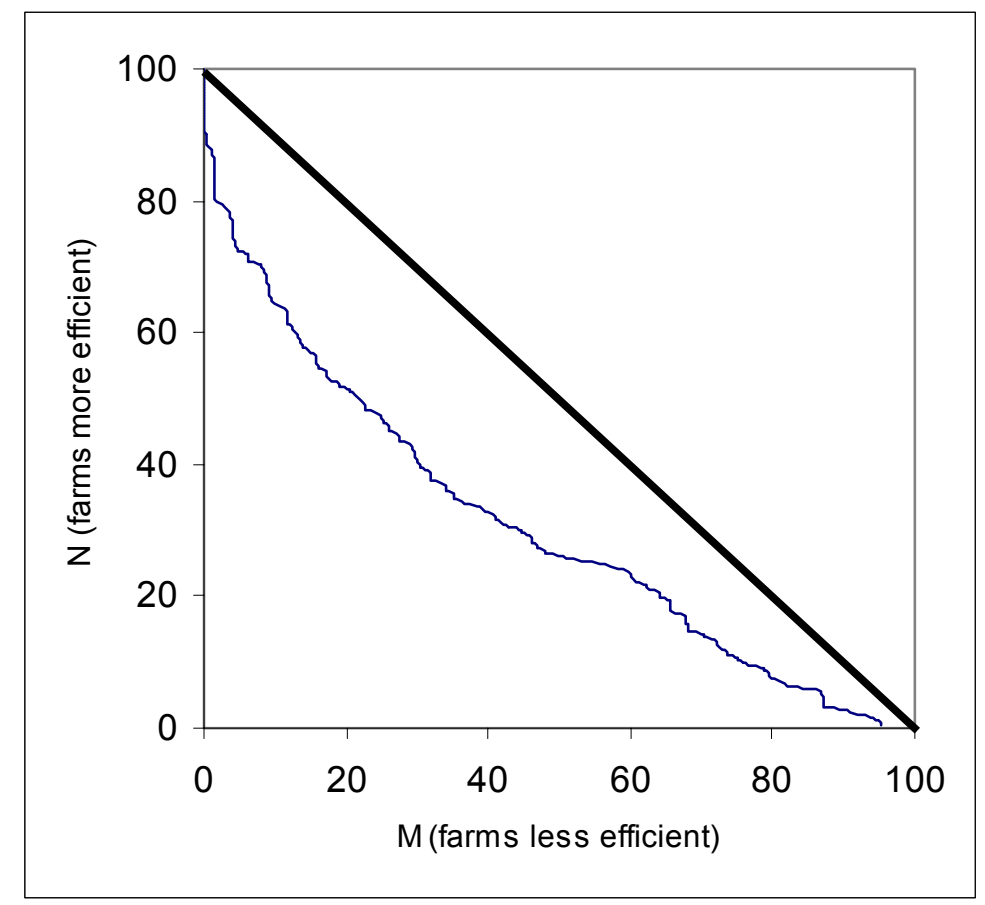




\section{Working Papers INRA - Unité ESR Rennes}

02-01 Tariff protection elimination and Common Agricultural Policy reform: Implications of changes in methods of import demand modelling. Alexandre GOHIN, Hervé GUYOMARD and Chantal LE MOUËL (March 2002)

02-02 Reducing farm credit rationing: An assessment of the relative effectiveness of two government intervention schemes. Laure LATRUFFE and Rob FRASER (April 2002)

02-03 Farm credit rationing and government intervention in Poland. Laure LATRUFFE and Rob FRASER (May 2002)

02-04 The New Banana Import Regime in the European Union: A Quantitative Assessment. Hervé GUYOMARD and Chantal LE MOUËL (July 2002)

02-05 Determinants of technical efficiency of crop and livestock farms in Poland. Laure LATRUFFE, Kelvin BALCOMBE, Sophia DAVIDOVA, and Katarzyna ZAWALINSKA (August 2002)

02-06 Technical and scale efficiency of crop and livestock farms in Poland: Does specialisation matter? Laure LATRUFFE, Kelvin BALCOMBE, Sophia DAVIDOVA, and Katarzyna ZAWALINSKA (October 2002) 